\title{
Leaf wax composition and distribution of Tillandsia landbeckii reflects moisture gradient across the hyperarid Atacama Desert
}

\author{
Sergio Contreras ${ }^{1,2} \cdot$ Manlio Landahur $^{1} \cdot$ Karla García $^{3} \cdot$ Claudio Latorre $^{4,5,6} \cdot$ Mark Reyers $^{7} \cdot$ Janet Rethemeyer $^{8}$. \\ Andrea Jaeschke ${ }^{8}$ (i)
}

Received: 31 October 2021 / Accepted: 15 December 2021 / Published online: 6 January 2022

(c) The Author(s) 2022

\begin{abstract}
In the hyperarid Atacama Desert, water availability plays a crucial role in allowing plant survival. Along with scant rainfall, marine advective fog frequently occurs along the coastal escarpment fueling isolated mono-specific patches of Tillandsia vegetation. In this study, we investigate the lipid biomarker composition of the bromeliad Tillandsia landbeckii (CAM plant) to assess structural adaptations at the molecular level as a response to extremely arid conditions. We analyzed long-chain $n$-alkanes and fatty acids in living specimens $(n=59)$ collected from the main Tillandsia dune ecosystems across a $350 \mathrm{~km}$ coastal transect. We found that the leaf wax composition was dominated by $n$-alkanes with concentrations (total average $160.8 \pm 91.4 \mu \mathrm{g} / \mathrm{g})$ up to three times higher than fatty acids $(66.7 \pm 40.7 \mu \mathrm{g} / \mathrm{g})$, likely as an adaptation to the hyperarid environment. Significant differences were found in leaf wax distribution (Average Chain Length [ACL] and Carbon Preference Index [CPI]) in the northern zone relative to the central and southern zones. We found strong negative correlations between fatty acid CPI and $n$-alkane ACL with precipitation and surface evaporation pointing at fine-scale adaptations to low moisture availability along the coastal transect. Moreover, our data indicate that the predominance of $n$-alkanes is reflecting the function of the wax in preventing water loss from the leaves. The hyperarid conditions and good preservation potential of both $n$-alkanes and fatty acids make them ideal tracers to study late Holocene climate change in the Atacama Desert.
\end{abstract}

Keywords Atacama desert $\cdot$ Fatty acids $\cdot$ Fog ecosystems $\cdot$ Leaf-wax $\cdot n$-alkanes $\cdot$ Tillandsia landbeckii

\section{Introduction}

Handling editor: Marcus Koch.

Sergio Contreras and Andrea Jaeschke have contributed equally.

Contribution to "Living at its dry limits - Tillandsiales in the Atacama Desert".

Sergio Contreras

scontreras@ucsc.cl

$\triangle$ Andrea Jaeschke

andrea.jaeschke@uni-koeln.de

1 Departamento de Química Ambiental, Facultad de Ciencias, Universidad Católica de la Santísima Concepción, Concepción, Chile

2 Centro de Investigación en Biodiversidad y Ambientes Sustentables, CIBAS, Concepción, Chile

3 Consorcio Eólico, Desarrollo de Proyectos de Energías Renovables, Concepción, Chile
The Atacama Desert is considered to be one of the oldest and most arid deserts on Earth and is an extreme habitat for life development (McKay et al. 2003; Hartley et al. 2005). The aridity in the Atacama Desert is caused principally by cold coastal waters that characterize the Humboldt Current and the upwelling of cold deep water to the surface, which

Centro UC Desierto de Atacama, Santiago, Chile

5 Departamento de Ecología, Pontificia Universidad Católica de Chile, Santiago, Chile

6 Instituto de Ecología \& Biodiversidad (IEB), Casilla 653, Santiago, Chile

7 Institute for Geophysics and Meteorology, University of Cologne, Cologne, Germany

8 Institute of Geology and Mineralogy, University of Cologne, Cologne, Germany 
creates an atmospheric thermal inversion preventing precipitation along the coastal zone (Houston and Hartley 2003). The aridity is intensified by the rain shadow effect of the Andean Mountains that blocks the transfer of moisture from the Amazon basin (Houston and Hartley 2003; Cereceda et al. 2008; Garreaud et al. 2008). As a result, the Atacama Desert has a hyperarid core characterized by mean annual precipitation lower than $2 \mathrm{~mm}$ between 19 and $22^{\circ} \mathrm{S}$ (Ritter et al. 2019; Voigt et al. 2020). Although the extremely low moisture supply to the Atacama Desert is not constant and varies geographically (e.g., latitude, distance inland and elevation), there is a clear latitudinal trend of the scarce precipitation increasing toward the north along the hyperarid core and over the coastal area (Schulz et al. 2011; Jaeschke et al. 2019; Reyers et al. 2021).

Besides infrequent rainfalls, marine advective fog from the Pacific Ocean is the most important source of moisture along the Atacama Desert (Cereceda et al. 2008; Lobos Roco et al. 2018; Schween et al. 2020; Del Río et al. 2021). Frequent coastal fog events are generally considered to be restricted to distances of up to a few kilometers from the coast and elevations of about 100-1200 m (Caviedes 1973; Prohaska 1973; García et al. 2021; Del Río et al. 2021). Beyond these elevations, hyperarid conditions limit the growth and survival of plants on the landscape and extensive areas without any vegetation exist, especially in the hyperarid core of Atacama Desert (Arroyo et al. 1988; Rundel and Dillon 1998; Schulz et al. 2011; Knief et al. 2020; Merklinger et al. 2020). Orographic fog oases are common along this coast and allow the development of unique plant communities (called lomas) of surprisingly high biodiversity in northern Chile and southern Peru (Rundel et al. 1991; Pinto et al. 2006; Merklinger et al. 2020). Fog corridors are unequally distributed and the hills are often isolated from each other by large expanses of barren landscape (García et al. 2021). Among these hill formations, the "Tillandsiales" hills stand out with its unique vegetation communities specialized for living in the Atacama Desert. The dominant species of this type of formation is Tillandsia landbeckii Phil. (Bromeliaceae family), one of 15 species of the genus Tillandsia, that survive in such extremely arid conditions by developing specialized adaptations for water collection (Rundel et al. 1997; Rundel and Dillon 1998; Pinto et al. 2006; Latorre et al. 2011). Of these 15, only three species are present in the coastal Atacama Desert of northern Chile: T. landbeckii, T. marconae Till \& Vitek and rarely T. virescens and T. capillaris Ruiz \& Pavon (Rundel and Dillon 1998; Schulz et al. 2011; Merklinger et al. 2020). The geographic distribution of $T$. landbeckii extends from southern Peru to the Coquimbo region in Chile $\left(31.65^{\circ} \mathrm{S}\right)$ (Smith and Downs 1977; Till 1992) and is restricted to the occurrence and elevation of fog belts (Oka and Ogawa 1984; Ono 1986).
Most Tillandsia plants are growing epiphytically on sandy surfaces, rocks or other plants, while some species even grow unrooted (i.e., epiarenic) on bare sand (Rundel et al. 1997; Rundel and Dillon 1998). The plants have no functional root system for water uptake therefore, they almost exclusively depend on the water and nutrients supplied by coastal fog (Pinto et al. 2006; Westbeld et al. 2009; Borthagaray et al. 2010; Gonzalez et al. 2011; Raux et al. 2020). The water uptake is carried out by highly specialized leaf trichomes unique to this plant family, which collect fog at night (Benzing et al. 1978; Rundel et al. 1997; Raux et al. 2020). The trichome of Tillandsia is formed by a shield of dead cells, with an unusually thick outer cell wall and located next to a cuticle which sits on top of the dome cell (Raux et al. 2020). The cuticle is an efficient and flexible barrier (Riederer and Schreiber 2001), constituted by cutine which is a structural component of this barrier composed of polyesters (Kolattukudy and Espelie 1985; Kunst and Samuels 2003; Jetter et al. 2006) and waxes embedded in the cutine. The water permeability of the cuticle determines the minimal and unavoidable water loss when the stomata are maximally closed during dry periods (Schuster et al. 2016). This physiological adaptation to extreme water uptake efficiency is accompanied by assimilation of carbon using Crassulacean Acid Metabolism (CAM) (Benzing et al. 1978). CAM metabolism is distinguished by the night time fixation of $\mathrm{CO}_{2}$ into malic acid allowing stomata to open only at nights when humidity is higher (Osmond et al. 1989; Haslam et al. 2003). Although CAM or a flexible $\mathrm{C}_{3}-\mathrm{CAM}$ mode of carbon fixation is known from epiphytic Tillandsia species of the coastal desert region (Rundel and Dillon 1998), foliar carbon isotope $\left(\delta^{13} \mathrm{C}\right)$ values of Tillandsia landbeckii of -12.5 to $-14.3 \%$ o (Latorre et al. 2011; Jaeschke et al. 2019) are in the typical narrow range of values corresponding to strong CAM species of bromeliads (Hermida-Carrera et al. 2020).

Leaf waxes of higher terrestrial plants are lipids that are insoluble in water (Bianchi and Canuel 2011) and contain a mixture of homologous series of long chain $(>23$ carbon atoms) compounds such as fatty acids, $n$-alkanes, alcohols and aldehydes (Kunst and Samuels 2003; Koch and Ensikat 2008; Tafolla-Arellano et al. 2013). These leaf waxes play an important role in plant physiology and ecology, being the first zone of protection, contact and interaction with other organisms, e.g., herbivores (Müller and Riederer 2005). Leaf waxes also have the function of limiting water loss through the cuticle, minimizing the exchange of gases (e.g., $\mathrm{CO}_{2}, \mathrm{O}_{2}$ ) and water $\left(\mathrm{H}_{2} \mathrm{O}\right)$, acting as a thermoregulator barrier (Jeffree 2006; Jetter et al. 2006). Waxes also minimize the wettability and retention of dust particles and spores, and act as shield against insects and UV radiation (Tafolla-Arellano et al. 2013). The $n$-alkyl waxes such as fatty acids and long-chain alkanes can be characterized by their dominant homologue, 
total abundance, and distribution (Eglinton and Hamilton 1967; Sharma et al. 2018; Dragota and Riederer 2009). The most common indices to evaluate distribution changes of these leaf waxes are the Carbon Preference Index (CPI), which measures the relative abundance of chain length with even over odd carbon dominance in long chain fatty acids or odd over even in $n$-alkanes (Eglinton and Hamilton 1967; Sachse et al. 2006) and the average chain length index (ACL). Plant wax $n$-alkanes and fatty acids occur in modern and fossil leaves. Both are stable and long-lived molecules that can survive in the fossil record and thus serve as valuable biomarkers for past environmental conditions potentially encompassing thousands or even millions of years in soils and sediments, respectively (Eglinton and Eglinton 2008; Bush and McInerney 2013; Diefendorf and Freimuth 2017; Finstad et al. 2018).

Previous investigations of Tillandsia plants in northern Chile have studied the geographic distribution, genetic diversity, and the variation of stable carbon and nitrogen isotopes in their tissues reflecting the variability of water and nutrient supply (Pinto et al. 2006; González et al. 2011; Latorre et al. 2011; Jaeschke et al. 2019; Koch et al. 2020; Merklinger et al. 2020). However, there are currently no reports on the specific composition of leaf waxes (fatty acids and $n$-alkanes) in these plants. The abundance and distribution of fatty acids and $n$-alkanes are important chemometric and environmental indicators, since according to their changes in abundance and distribution, changes in water availability, water stress and taxonomic prevalence can be inferred (Bush and McInerney 2013, 2015; Jaeschke et al. 2018; Andrae et al. 2019; Struck et al. 2020; Mörchen et al. 2021; RuizRuiz et al. 2021). In addition, knowing the detailed composition of these waxes is the first step to more complex analyses such as compound-specific carbon, hydrogen and nitrogen isotope analyses, which can provide additional information of their photosynthetic metabolism and origin of their water source, respectively.

This study quantifies and compares the abundance and distribution (CPI and ACL) of leaf waxes, specifically long chain $n$-fatty acids $\left(\mathrm{C}_{24}-\mathrm{C}_{34}\right)$ and $n$-alkanes $\left(\mathrm{C}_{23}-\mathrm{C}_{33}\right)$ from individuals of Tillandsia landbeckii sampled along the coastal hyperarid core of Atacama Desert (18.47-21.21 ${ }^{\circ} \mathrm{S}$ ), and correlating with geographic (latitude, elevation, distance inland) and environmental (precipitation, temperature, surface evaporation) characteristics. Our comprehensive survey of variation among Tillandsia-specific leaf waxes will provide new insights into unique adaptation strategies for life at the dry limit.

\section{Material and methods}

\section{Study area and sampling strategy}

The northwestern coast of South America is characterized by low rainfall and a coastal desert spanning from Peru to northern Chile, politically and geographically separated in Sechura Desert (Peruvian coast between Piura and Tacna) and Atacama Desert (Contreras et al. 2010). The Atacama Desert extends west of the central Andes between 15 and $30^{\circ} \mathrm{S}$ across southern Peru and northern Chile (Houston and Hartley 2003). The coastal Cordillera in northern Chile with elevations of approximately $1000-1600 \mathrm{~m}$ a.s.l. separates the narrow coastal plain from the broad Central Valley. The study area is located in the coastal mountain range of the Chilean Atacama Desert (Fig. 1). The climate is generally mild with uniform annual air temperature of $18.9^{\circ} \mathrm{C}$ in Arica and $18.4{ }^{\circ} \mathrm{C}$ in Iquique (Schulz et al. 2011). Annual precipitation is extremely low ( $<2 \mathrm{~mm}$; Schulz et al. 2011; Reyers et al. 2021) and rainfall is largely restricted to austral winter (Houston 2006). Summer precipitation becomes more dominant in the northern Andean zone accounting for ca. $30 \%$ of annual rainfall at Arica (Houston 2006; Schulz et al. 2011). Fog occurs frequently along the coastal Cordillera when the massive marine Stratocumulus ( $\mathrm{Sc}$ ) cloud deck that covers a large portion of the subtropical southeast Pacific approaches the coastal cliff (Cereceda et al. 2008; Schween et al. 2020; Del Río et al. 2021). Advection of marine Sc air masses facilitate fog formation in the morning and evening/ night, while changes in air circulation during the afternoon produce thermal stratification that dissipates fog (Muñoz et al. 2016; Lobos Roco et al. 2018; Schween et al. 2020). The maximum spatial extent of fog typically occurs during the winter months from June to August (Del Río et al. 2018; Schween et al. 2020).

We examined nine of the largest Tillandsia ecosystems (Rundel et al., 1997; Pinto et al. 2006; Latorre et al. 2011; Koch et al. 2019) located in the coastal mountains at elevations of 900-1200 m a.s.l. between Arica and the Rio Loa Canyon (ca. $18.5-21.5^{\circ} \mathrm{S}$ ) in March 2017 (Jaeschke et al. 2019). Tillandsia landbeckii is the predominant species, but occasionally, $T$. virescens, $T$. capillaris and T. marconae coexist, in particular toward the northern range of occurrence close to the border with Peru (Rundel et al. 1997; Pinto et al. 2006; Merklinger et al. 2020). The communities are located at distances to the coast ranging from $3 \mathrm{~km}$ at site 8 (Cerro Chipana) to about $27 \mathrm{~km}$ at site 9 located at Quebrada Rio Loa (Fig. 1; Table 1). They form either dense units or sparse and isolated stands on W and SW facing slopes directly exposed to fog. Stem and leaf tissue from multiple specimens were collected from each Tillandsia landbeckii population to cover a range in elevation and assess natural 


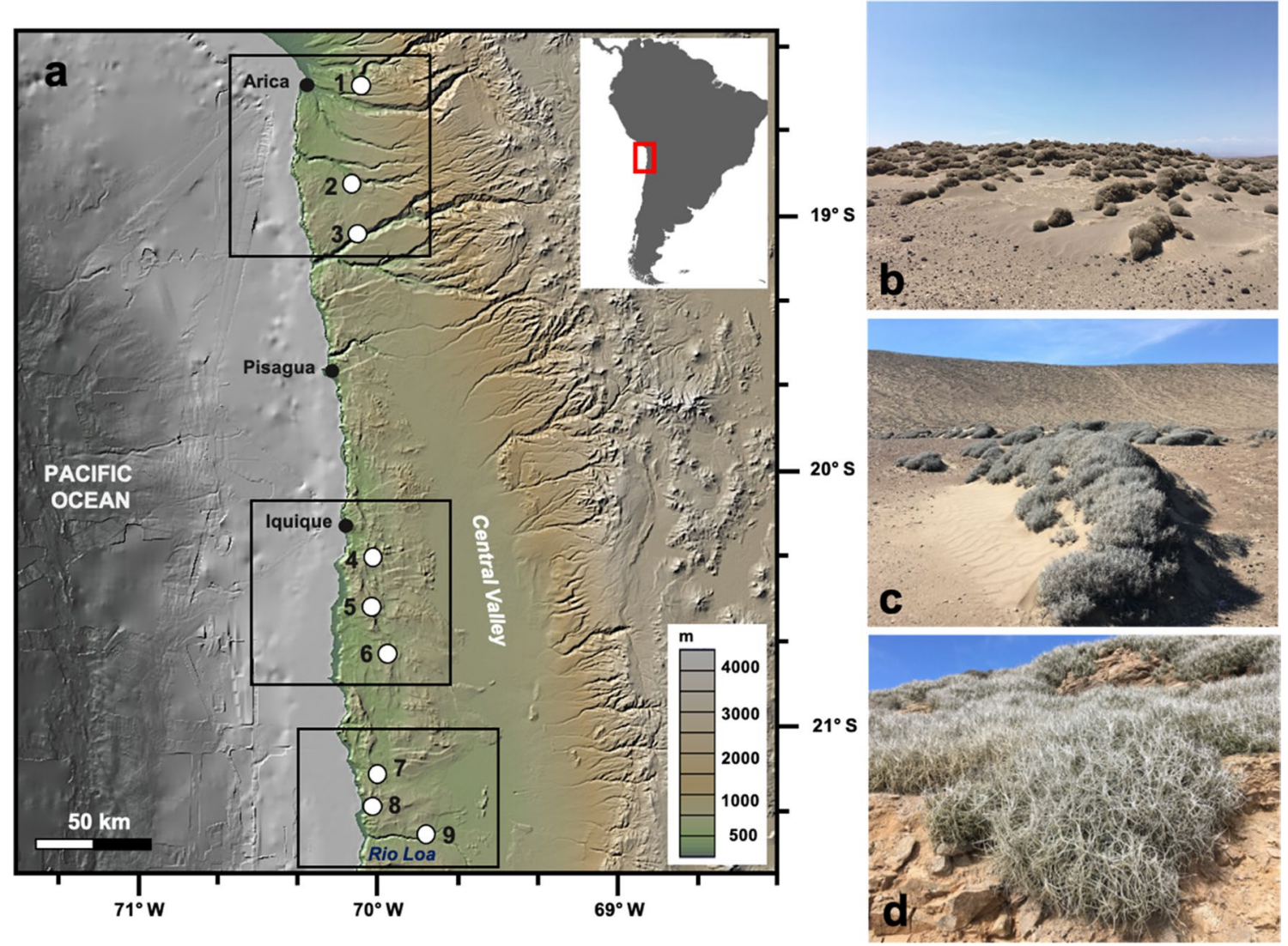

Fig. 1 a Map of the study area showing the locations of the Tillandsia fields along the Coastal Cordillera of the Atacama Desert in Northern Chile grouped in a northern (\#1-3), central (\#4-6) and southern (\#7-9) zone. Photographs of the typical Tillandsia vegetation on small dunes at $\mathbf{b}$ Quebrada Camarones (\#3) and $\mathbf{c}$ Cerro Oyarbide (\#5) or attached to rocky surfaces at Cerro Chipana (\#8)
Table 1 Location and environmental data of Tillandsia landbeckii fields in northern Chile. Precipitation (Precip), temperature (Temp) and surface evaporation (Surf evap) are given as climatological annual means. Site-averaged stable carbon isotope $\left(\delta^{13} \mathrm{C}\right)$ values of Tillandsia landbeckii whole plant material indicative of CAM metabolism

\begin{tabular}{|c|c|c|c|c|c|c|c|c|}
\hline Site $\mathrm{Nr}^{\mathrm{a}}$ & $\begin{array}{l}\text { Latitude } \\
{ }^{\circ} \mathrm{S}\end{array}$ & Longitude ${ }^{\circ} \mathrm{W}$ & $\begin{array}{l}\text { Elevation (m } \\
\text { a.s.l.) }\end{array}$ & $\begin{array}{l}\text { Distance } \\
\text { coast }(\mathrm{km})\end{array}$ & $\begin{array}{l}\text { Precip a,b } \\
(\mathrm{mm} / \mathrm{y})\end{array}$ & $\begin{array}{l}\text { Temp } \\
\left({ }^{\circ} \mathrm{C}\right)^{\mathrm{b}}\end{array}$ & $\begin{array}{l}\text { Surf evap } \\
(\mathrm{mm} / \mathrm{y})^{\mathrm{b}}\end{array}$ & $\delta^{13} \mathrm{C}(\% \circ \mathrm{VPDB})^{\mathrm{a}}$ \\
\hline \multicolumn{9}{|c|}{ Northern zone } \\
\hline 1 & $18^{\circ} 28^{\prime} 37.6^{\prime \prime}$ & $70^{\circ} 04^{\prime} 51.5^{\prime \prime}$ & 1000 & 23.6 & 1.50 & 13.7 & 5.63 & -13.0 \\
\hline 2 & $18^{\circ} 52^{\prime} 31.4^{\prime \prime}$ & $70^{\circ} 07^{\prime} 12.9^{\prime \prime}$ & 1043 & 22.4 & 1.13 & 16.3 & 5.71 & -13.4 \\
\hline 3 & $19^{\circ} 04^{\prime} 21.9^{\prime \prime}$ & $70^{\circ} 06^{\prime} 26.8^{\prime \prime}$ & 1100 & 20.8 & 1.05 & 16.0 & 5.34 & -13.1 \\
\hline \multicolumn{9}{|c|}{ Central zone } \\
\hline 4 & $20^{\circ} 20^{\prime} 08.8^{\prime \prime}$ & $70^{\circ} 01^{\prime} 54.3^{\prime \prime}$ & 1067 & 12.7 & 0.95 & 15.4 & 3.65 & -13.3 \\
\hline 5 & $20^{\circ} 31^{\prime} 30.6^{\prime \prime}$ & $70^{\circ} 02^{\prime} 43.0^{\prime \prime}$ & 1157 & 15.7 & 0.66 & 15.1 & 3.49 & -14.3 \\
\hline 6 & $20^{\circ} 43^{\prime} 33.7^{\prime \prime}$ & $69^{\circ} 58^{\prime} 13.8^{\prime \prime}$ & 1014 & 23.3 & 0.48 & 15.0 & 3.29 & -12.6 \\
\hline \multicolumn{9}{|c|}{ Southern zone } \\
\hline 7 & $21^{\circ} 10^{\prime} 40.6^{\prime \prime}$ & $70^{\circ} 00^{\prime} 31.3^{\prime \prime}$ & 942 & 10.0 & 0.53 & 14.4 & 4.90 & -13.2 \\
\hline 8 & $21^{\circ} 18^{\prime} 22.7^{\prime \prime}$ & $70^{\circ} 01^{\prime} 32.8^{\prime \prime}$ & 987 & 4.5 & 0.58 & 13.8 & 4.76 & -13.9 \\
\hline 9 & $21^{\circ} 24^{\prime} 38.5^{\prime \prime}$ & $69^{\circ} 48^{\prime} 33.2^{\prime \prime}$ & 1028 & 27.5 & 0.51 & 14.7 & 3.45 & -12.9 \\
\hline
\end{tabular}

${ }^{a}$ According to Jaeschke et al. (2019)

${ }^{\mathrm{b}}$ Derived from the WRF model (Reyers 2019) 
heterogeneity (Jaeschke et al. 2019). Samples were stored in geochemical bags and allowed to air-dry before shipping to Germany.

\section{Leaf wax analysis}

Plant material was first rinsed with deionized water to remove surficial mineral dust and particles and then dried in a convection oven at $40{ }^{\circ} \mathrm{C}$. Leaves and stems of each plant sample were ground and homogenized. Bulk plant material of 59 samples (ca. $1 \mathrm{~g}$ ) was ultrasonically extracted using a mixture of dichloromethane (DCM) and methanol $(2: 1, \mathrm{v} / \mathrm{v})$, three times repeated. The extracts were combined and the bulk of the solvent subsequently removed by rotary evaporation under vacuum. The resulting total lipid extracts (TLE) were separated into apolar (with $n$-hexane), and polar (with DCM:methanol; $1: 1, \mathrm{v} / \mathrm{v}$ ) fractions using activated silica gel chromatography. The apolar fractions containing $n$-alkanes were further separated into saturated and unsaturated compounds over a small column filled with $\mathrm{AgNO}_{3}$-coated silica gel $(10 \% \mathrm{w} / \mathrm{w})$ and $n$-hexane and DCM, respectively. The polar fraction was separated into fatty acids and neutrals over a aminopropyl column with glacial acetic:diethyl-ether $(1 / 24, v / v)$ and methanol, respectively. The fatty acid fractions were methylated with $500 \mu \mathrm{L}$ of boron trifluoride in methanol, generating fatty acid methyl esters (FAMEs) prior to instrumental analysis. $n$-Alkanes were analyzed at the University of Cologne using a gas chromatograph equipped with an on-column injector and a flame ionization detector (GC-FID; HP 5890 series II) and fatty acids were analyzed at the Universidad Católica de la Santísima Concepción using a gas chromatograph with a Split/Splitless injector and a flame ionization detector (GC-FID 7890A; Agilent Technologies).

\section{n-Alkane and fatty acid indices}

The carbon preference index (CPI) was calculated using the abundances of odd- and even-numbered chain lengths from $\mathrm{C}_{23}$ to $\mathrm{C}_{34}$ for $n$-alkanes and fatty acids as follows:

CPI (alkanes $)=0.5 \times[(\Sigma$ even $/ \Sigma$ odd $)+(\Sigma$ even $/ \Sigma$ odd $)]$.

CPI $($ fatty acids $)=0.5 \times[(\Sigma$ odd $/ \Sigma$ even $)+(\Sigma$ odd $/ \Sigma$ even $)]$.

The average chain length (ACL) of $n$-alkanes was calculated as follows:

$\mathrm{ACL}_{23-34}=\Sigma\left(\mathrm{C}_{n} \times n\right) / \Sigma(n)$

where $\mathrm{C} n$ is the abundance of each $n$-alkane or fatty acid with $n$ carbon atoms for chain lengths from $\mathrm{C}_{23}$ to $\mathrm{C}_{34}$.

\section{Environmental data}

Estimates on mean annual precipitation and actual surface evaporation are derived from a long-term simulation with the Weather Research and Forecasting (WRF) regional climate model v3.9 (Skamarock et al. 2008). The simulation covers the period 1982 to 2017 using actual atmospheric conditions from the ERA-Interim reanalysis dataset (Dee et al. 2011) as boundary conditions and a horizontal resolution of $10 \times 10 \mathrm{~km}$ is obtained using a double one-way nesting. A detailed description of the model setup, including details to the applied parameterizations, is given in Reyers et al. (2021). WRF simulated precipitation is validated against station measurements, and it shows good agreement with the rainfall observations particularly for the hyperarid core of the Atacama Desert (Reyers et al. 2021). The model output has an hourly temporal resolution, such that different statistics can be derived, including climatological means as used in this study. For each Tillandsia location on land, the value from the nearest grid cell was considered for comparison. Simulated daily accumulated climate data are freely available (Reyers 2019).

\section{Statistical analysis}

As the distribution of the data was not normal, we applied a Kruskal-Wallis test (non-parametric ANOVA) to estimate differences between leaf waxes for geographic zones, abundance and distribution (CPI and ACL) per zones. A Dunn's test was used to determine whether or not there is a statistically significant difference between the medians of the three zones. To assess the effect of environmental and geographic parameters on the abundance and distribution of the leaf wax compounds, we used a Spearman's correlation. The software Statistica 10.0.228.2 was used for statistical analysis.

\section{Results and discussion}

\section{Leaf wax abundance}

The leaf wax class dominant in Tillandsia landbeckii are $n$-alkanes (Fig. 2a) with an average concentration three times higher than fatty acids considering all the individuals analyzed $(n=59)$. The highest difference among leaf wax classes was found in the Central Zone reaching $n$-alkane abundances almost four times higher than fatty acids. There are few studies evaluating the composition of different leaf wax classes from plants in South America, mainly restricted to tropical areas (Jansen et al. 2006; Feakins et al. 2016) and temperate forests (Dodd et al. 1998; Rafii and Dodd 1998; Cifuentes et al. 2020; Cerda-Peña et al. 2020), where long chain fatty acids were mostly dominant compared with 


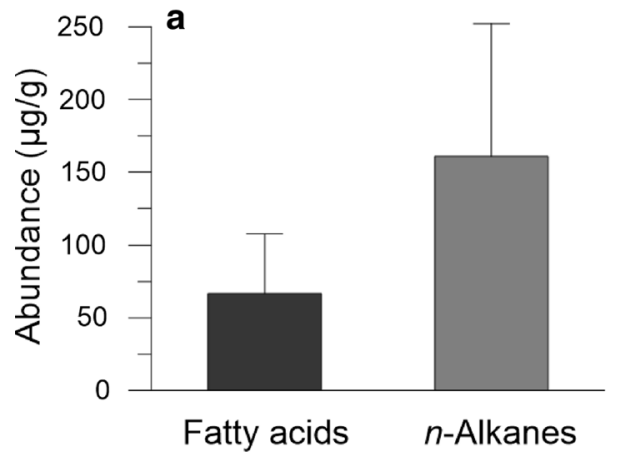

Fig. 2 Average abundances of fatty acids (black bars) and $n$-alkanes (grey bars) in fog-affected Tillandsia landbeckii of northern Chile a and per zones $\mathbf{b}$ along a N-S gradient between Arica and the Rio Loa canyon (North $n=13$, Central $n=23$, South $n=23$ ). The bars show

$n$-alkanes (Fig. S1). A higher concentration of $n$-alkanes in leaf waxes might confer to Tillandsia landbeckii individuals a more hydrophobic wax layer to avoid the loss of water from the leaves. In fact, a predominance of leaf wax $n$-alkanes compared with leaf wax fatty acids had been reported in two species of plants living in the Gobi Desert, located between Mongolia and China (Xu et al. 2020). The $n$-alkanes are produced metabolically from the fatty acids (Kolattukudy, 1966) and are the most effective wax constituents in reducing the permeability of cuticule barriers (Kosma et al. 2009; Xu et al. 2016). Therefore, the Tillandsia plants could synthesize higher amounts of $n$-alkanes to minimize water loss as an adaptation to extreme drought stress (Xu et al. 2020).

The dominance of $n$-alkanes is also visible in all three sampling zones (Fig. 2b) with the highest difference (almost 4 times higher) between average amount of both waxes in the Central Zone. The average abundance of leaf wax fatty acids was $77.1 \mu \mathrm{g} / \mathrm{gdl}$ with a range between 21.4 and $176.9 \mu \mathrm{g} /$ $\mathrm{gdl}$ in the Northern Zone, an average of $49.5 \mu \mathrm{g} / \mathrm{gdl}$ with a range between 10.9 and $117.6 \mu \mathrm{g} / \mathrm{gdl}$ in the Central Zone, and in the Southern Zone $65.7 \mu \mathrm{g} / \mathrm{gdl}$ with a range between 10.2 and $152.9 \mu \mathrm{g} / \mathrm{gdl}$ (Fig. 2b). The average abundance of leaf wax $n$-alkanes in the Northern Zone was $166.5 \mu \mathrm{g} / \mathrm{gdl}$ with a range between 80.1 and $305.8 \mu \mathrm{g} / \mathrm{gdl}$, the Central Zone hold an average of $193.8 \mu \mathrm{g} / \mathrm{gdl}$ ranging between 118.9 and $329.0 \mu \mathrm{g} / \mathrm{gdl}$, and Southern Zone had $160.2 \mu \mathrm{g} / \mathrm{gdl}$ on average ranging between 10.6 and $368.3 \mu \mathrm{g} / \mathrm{gdl}$ (Fig. 2b). The statistical analysis (Kruskal-Wallis) did not give any significant difference among zones considering both leaf waxes (for fatty acids $H=3.2136, p=0.2005$; for $n$-alkanes $H=1.0413, p=0.5941)$. The high variability in leaf wax abundance within a specific Tillandsia system most likely reflects the natural variability related to fine-scale changes in moisture supply and thus plant growth and fitness which was also observed in the Oyarbide field (Koch et al. 2019, 2020). In addition, age differences may also account for part

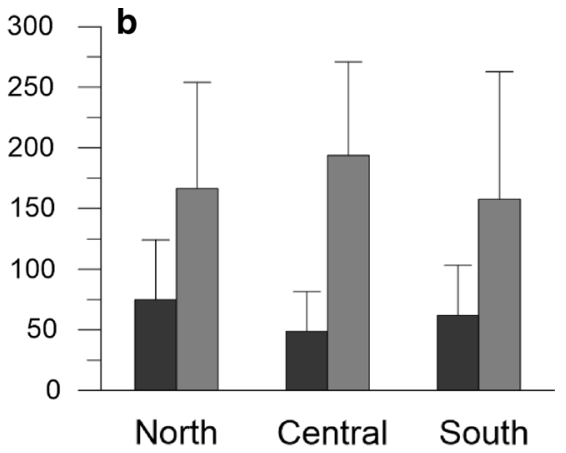

mean values \pm SD. Statistical analysis (Kruskal-Wallis test) showed no significant differences between zones (fatty acids: $H=3.213$, $p=0.2005, n$-alkanes: $\mathrm{H}=1.0413, p=0.5941)$

of the variability as we analyzed not only the youngest leaves but the whole plant including leaves and stems.

The total amount of $n$-alkanes stored in Tillandsia landbeckii is in the range of those reported for CAM plants of southwest Africa (Boom et al. 2014) and shrub vegetation (i.e., Poaceae, Cyperaceae, Artemisia spp.) of the Gobi Desert (Struck et al. 2020). Concentrations are however about 10-30 times lower compared to $\mathrm{C}_{3}$ shrub vegetation analyzed in the Paposo region of Chile at $\sim 24.5^{\circ} \mathrm{S}$, which is also affected by fog and slightly higher rainfall amount (Mörchen et al. 2021). This may relate to plant species-specific (i.e., CAM vs. $\mathrm{C}_{3}$ photosynthetic pathway) differences in leaf size and leaf wax production, density of stomata $v s$ trichomes covering leaves, water use efficiency and drought tolerance. In addition, $\mathrm{C}_{3}$ plants can benefit from soil moisture which is in general not available for rootless Tillandsia plants (Jaeschke et al. 2019).

\section{Leaf wax distribution}

Leaf wax fatty acid CPI values ranged between 2.5 and 11.1 with significant differences between zones $(H=20.047$, $p=0.0000)$. CPI values were considerably lower in the Northern Zone (average $=5.1$ ) than in the Central Zone (6.6) and Southern Zone average CPI (6.9) (Fig. 3a). CPI values of $n$-alkanes were less variable than those of fatty acids ranging between 6.9 and 11.3 with no significant differences between zones $(H=2.1090, p=0.3484)$ and averages in Northern Zone of 8.1, in the Central Zone of 8.3, and in the Southern Zone of 8.9 (Fig. 3b).

Tillandsia landbeckii is characterized by an almost homogenous distribution of the different homologues ranging between $\mathrm{C}_{23}-\mathrm{C}_{31}$ (n-alkanes) and $\mathrm{C}_{24}-\mathrm{C}_{32}$ (fatty acids) (Fig. 4). ACL values of fatty acids range between 24.6 and 30.2 with no significant differences among zones $(H=7.2309, p=0.0269)$. The ACL mean for the 

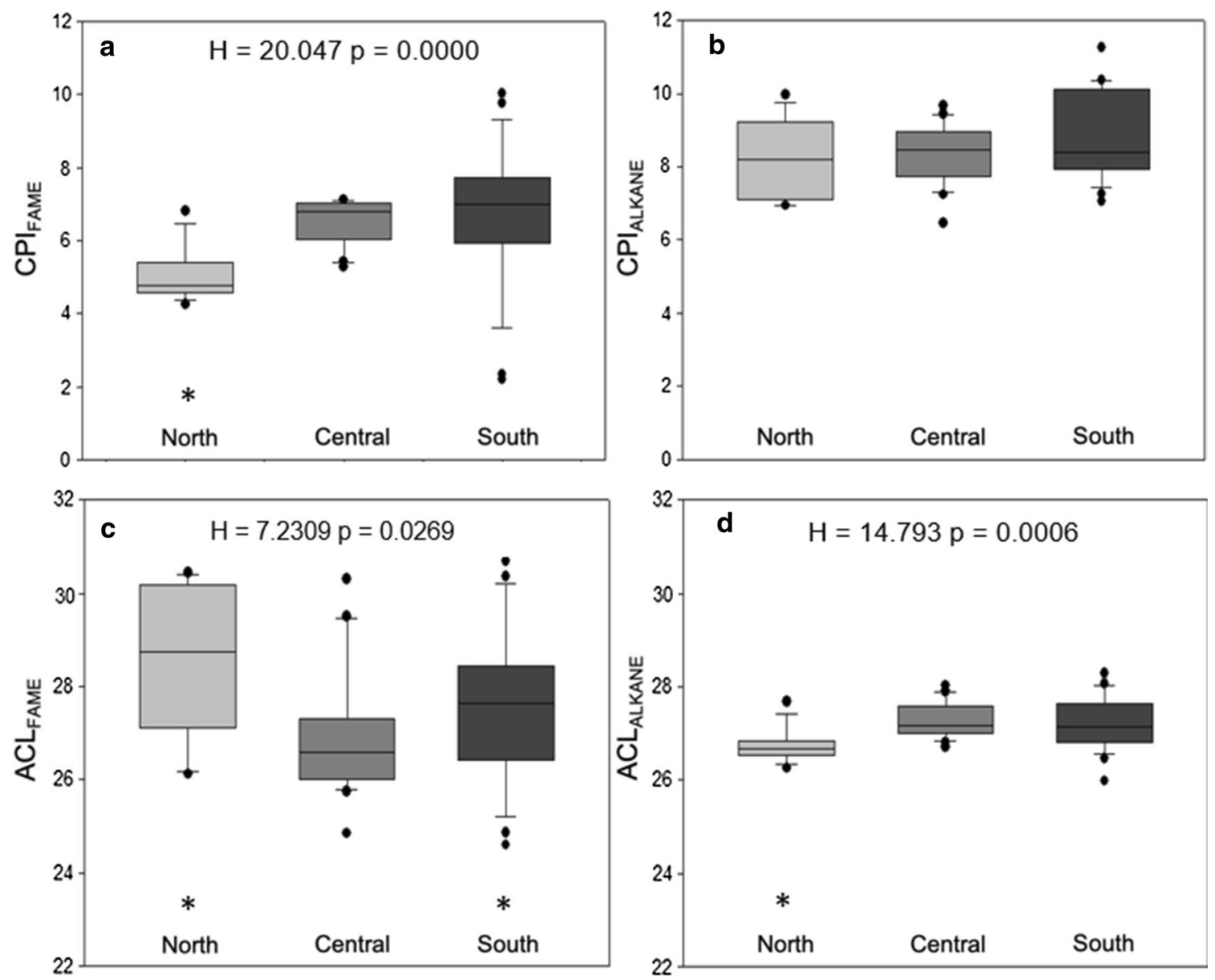

Fig. 3 Box plots divided by plant wax class for CPI (Carbon Preference Index) and ACL (Average Chain Length) of fatty acids (a, c) and $n$-alkanes $(\mathbf{b}, \mathbf{d})$ for the different geographical zones along the Coastal Cordillera (Northern Zone $n=13$, Central Zone $n=23$, Southern Zone $n=23$ ). Each box represents the range of middle $(50 \%)$ of group values, the horizontal line is group mean, and asterisk shows significant differences. In panels a and $\mathbf{d}$, significant differences were found between Northern Zone and Central and Southern Zone based on Kruskal-Wallis test with a $H=20.047, p=0.0000$

Northern Zone was 28.7, for the Central Zone 26.9, and for the Southern Zone 27.7 (Fig. 3c). Generally, a lower range in ACL values was observed for $n$-alkanes ranging from 26.0 to 28.3 (Fig. 3d), compared to fatty acid ACL values. Significant differences were found between the Northern Zone (26.7 ACL average) compared to the Central and Southern Zones (27.3 and 27.1 ACL average, respectively). The $n$-alkane pattern of Tillandsia landbeckii was markedly different compared to those reported for the shrub vegetation in the Atacama Desert (Mörchen et al. 2021), the Gobi Desert (Struck et al. 2020) or for CAM plants from arid southwest Africa (Boom et al. 2014), and ACL values are below those reported for $C_{3}$ or $\mathrm{C}_{4}$ plants compiled by Diefendorf and Freimuth (2017).

and d $H=14.793, p=0.0006$, respectively, showing differences in Northern Zone at both panels based on Dunn test $\left(Q_{\text {critic[a] }}=2.394\right.$; $Q_{1,2}=3.288 ; \quad Q_{1,3}=4.236 ; \quad Q_{2,3}=1.089 \quad$ and $\quad Q_{\text {critic[d] }}=2.394$; $\left.Q_{1,2}=3.724 ; Q_{1,3}=3.022 ; Q_{2,3}=0.895\right)$. In panel c, significant differences were found between Northern Zone and Central and Southern Zone based on Kruskal-Wallis test $(H=7.2309, p=0.0269)$, and based on Dunn test show differences in the Northern Zone with Central Zone, but equal with Southern Zone $\left(Q_{\text {critic }[\mathrm{c}]}=2.394\right.$; $\left.Q_{1,2}=2.560 ; Q_{1,3}=1.403 ; Q_{2,3}=1.424\right)$

A study by Feakins and Sessions (2010) also showed a tendency to longer chain lengths in drought-adapted succulent species peaking at $n-\mathrm{C}_{29}$ to $n-\mathrm{C}_{33}$ and extreme differences in abundance and distribution of the individual $n$-alkane homologues. Mörchen et al. (2021) proposed that fog-affected plants can be distinguished from rainaffected plants in the Atacama Desert by their specific $n$-alkane pattern dominated by $n-\mathrm{C}_{31}$. We cannot confirm these observations and suggest that the distinct $n$-alkane distribution in Tillandsia is rather typical for this plant type using CAM metabolism in this dry and relatively cold coastal desert (Table 1). 


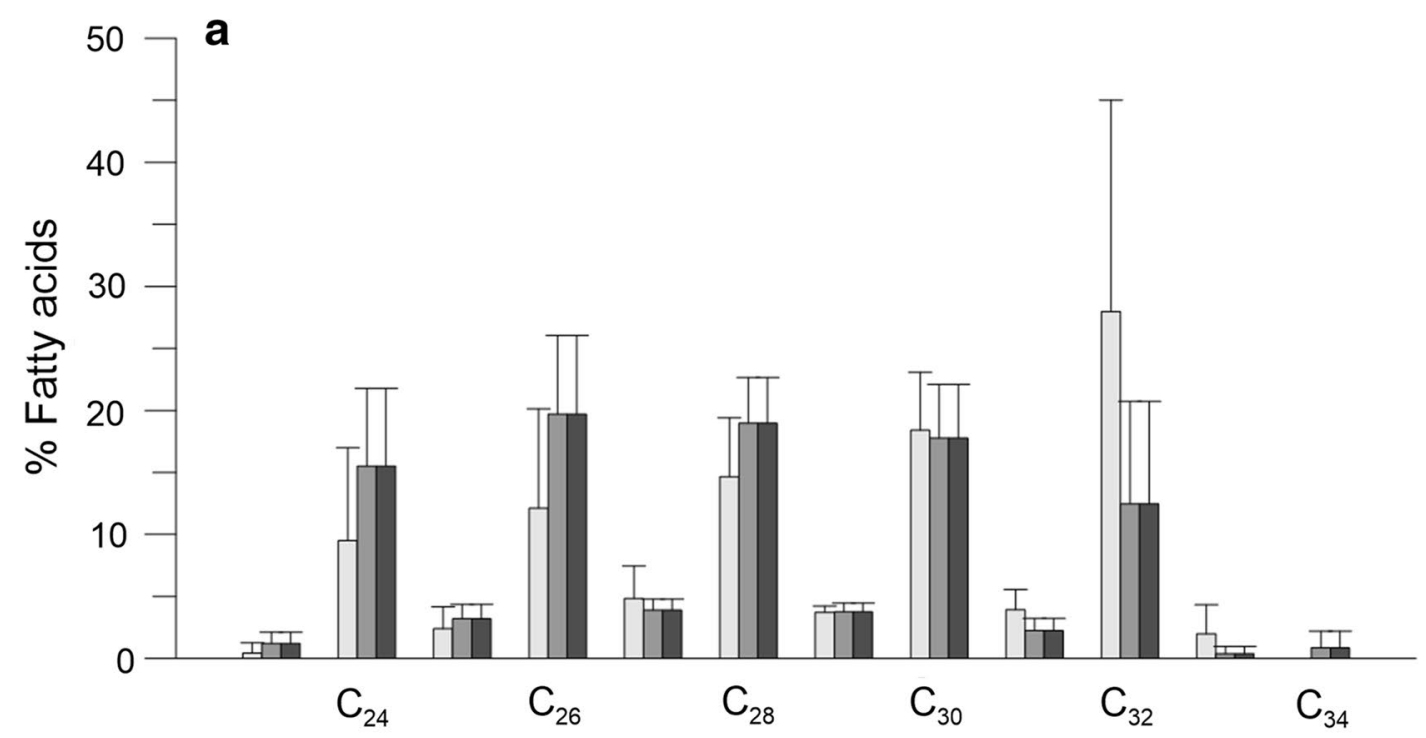

fatty acid chain length

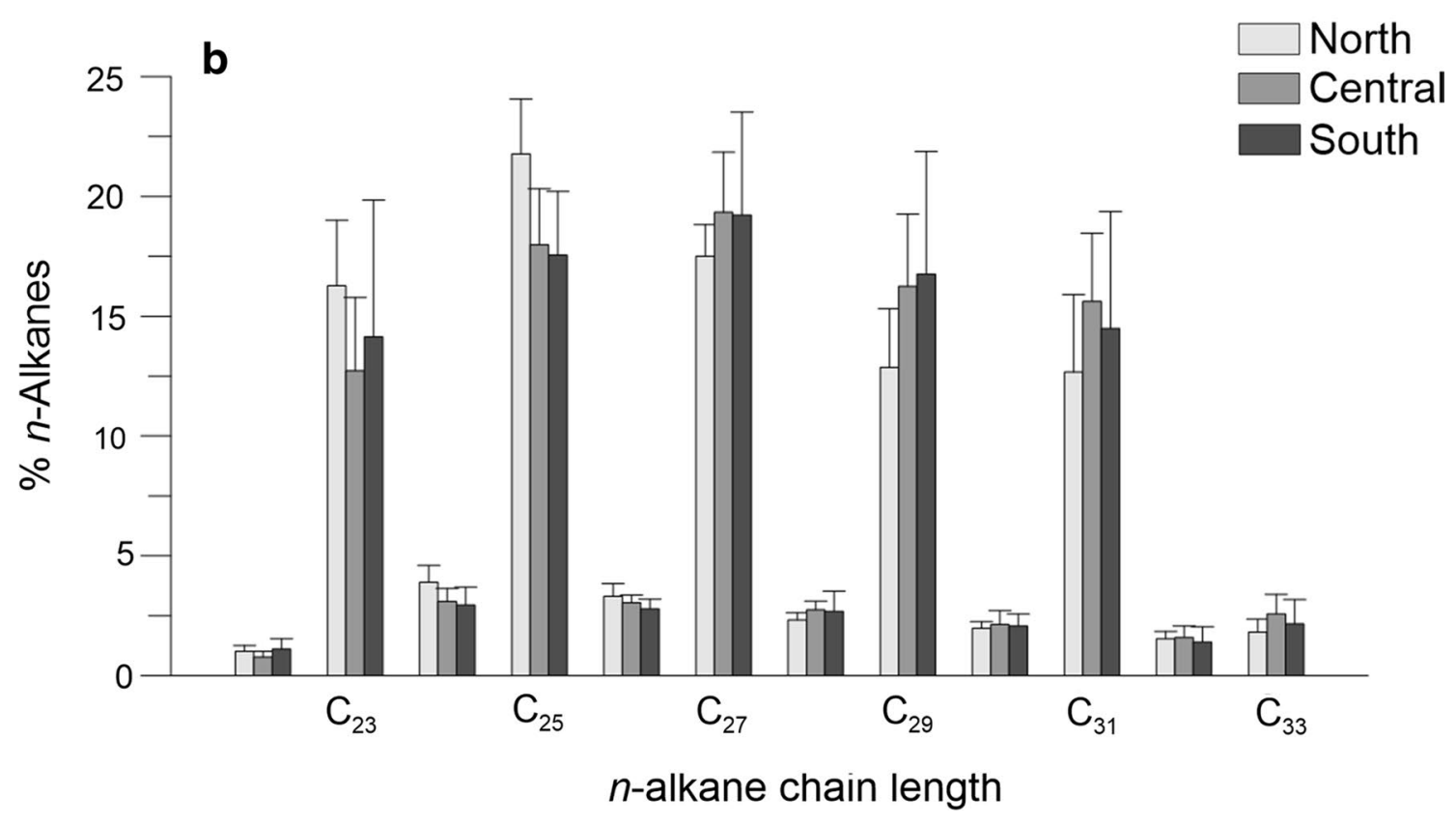

Fig. 4 Average chain length distribution of even fatty acids (a) and odd $n$-alkanes (b) in fog-affected Tillandsia landbeckii of northern Chile (North $n=13$, Central $n=23$, South $n=23$ ). The bars show mean values \pm SD

\section{Environmental influence on leaf wax abundance and distribution}

Environmental parameters such as rainfall, temperature and relative humidity can affect the composition of higher plant leaf wax (Sachse et al. 2006; Hoffmann et al. 2013; Bush and McInerney 2015; Jaeschke et al. 2018; Andrae et al. 2019). Because of the high intra-system variability of Tillandsia plant waxes described above, we use siteaverage abundances to better constrain relationships with climate parameters along the investigated coastal transect (Jaeschke et al. 2019).

The Mean Annual Precipitation (MAP) derived from the WRF simulation (Reyers 2019; Jaeschke et al. 2019) is extremely low at the study sites $(\leq 1.5 \mathrm{~mm} / \mathrm{yr})$. However, the highest significant Spearman's Rank correlation coefficient was observed between latitude and MAP $\left(r_{s}=-0.726\right.$; $p<0.001$, Table 2), showing a significant decrease in moisture content across the investigated transect. It's well known that the main source of moisture at the western coast 
Table 2 Spearman correlation matrix between geographic and climate variables and Tillandsia landbeckii $(n=59)$ along the Coastal Cordillera in northern Chile. Significant correlations $(p \leq 0.05)$ in italics and higher than 0.4 marked in bold

\begin{tabular}{|c|c|c|c|c|c|c|c|c|c|c|}
\hline & FA & ALK & $\mathrm{CPI}_{\mathrm{FA}}$ & $\mathrm{CPI}_{\mathrm{ALK}}$ & $\mathrm{ACL}_{\mathrm{FA}}$ & $\mathrm{ACL}_{\mathrm{ALK}}$ & Lat & Altitude & Distance & Precip \\
\hline ALK & 0.036 & & & & & & & & & \\
\hline $\mathrm{CPI}_{\mathrm{FA}}$ & 0.008 & -0.071 & & & & & & & & \\
\hline $\mathrm{CPI}_{\mathrm{ALK}}$ & -0.051 & 0.104 & 0.176 & & & & & & & \\
\hline $\mathrm{ACL}_{\mathrm{FA}}$ & 0.173 & -0.108 & -0.304 & -0.064 & & & & & & \\
\hline $\mathrm{ACL}_{\mathrm{ALK}}$ & -0.192 & 0.413 & 0.286 & -0.264 & -0.189 & & & & & \\
\hline Latitude & 0.007 & 0.117 & 0.580 & 0.100 & 0.001 & 0.303 & & & & \\
\hline Altitude & -0.059 & -0.094 & -0.256 & 0.011 & 0.105 & -0.152 & -0.411 & & & \\
\hline Distance & -0.060 & 0.161 & -0.384 & -0.425 & 0.093 & 0.021 & -0.266 & 0.051 & & \\
\hline Precip & -0.064 & -0.100 & -0.562 & 0.107 & 0.225 & -0.416 & -0.726 & 0.451 & -0.066 & \\
\hline Surf evap & 0.165 & -0.261 & -0.301 & 0.123 & 0.231 & -0.485 & -0.417 & -0.034 & -0.235 & 0.727 \\
\hline
\end{tabular}

of Northern South America is associated to the seasonal migration of the Intertropical Convergence Zone (Takahashi and Battisti 2007). However, latitude correlates significantly and negatively also with actual surface evaporation but to a lower degree $\left(r_{s}=-0.417 ; p<0.001\right)$. It is important to remember that we are talking at very low levels and scarce (infrequent) precipitation, thus fog must play a significant role as moisture source (Lobos-Roco et al. 2018; Schween et al. 2020; Böhm et al. 2021; Del Rio et al. 2021; García et al. 2021). A significant and positive trend was observed between precipitation and elevation $\left(r_{s}=0.451 ; p<0.001\right.$, Table 2), which may relate to the higher water content at the top of the Sc cloud deck (Cereceda et al. 2008; Latorre et al. 2011; Jaeschke et al. 2019). However, neither water content of the Sc cloud or fog are included in the WRF precipitation, which may explain some of the variability seen in our data. A promising fog-detecting approach was recently introduced by Böhm et al. (2021) and may help to disentangle the influence of different moisture sources on Tillandsia lomas.

The abundance of leaf wax fatty acids did not show significant correlations with any of the climate variables. However, the $n$-alkane abundance correlates significantly and positively with ACL of $n$-alkanes $\left(r_{s}=0.413 ; p<0.001\right)$ and negatively with surface evaporation $\left(r_{s}=-0.261 ; p<0.05\right)$. Therefore, increasing abundance of $n$-alkanes are related with an increase in abundance of longer chain length of $n$-alkanes. In addition, the low but significant correlation with surface evaporation suggests an increase of $n$-alkanes at low moisture conditions. CPI of fatty acids correlates significantly with many variables but the highest correlations were observed with latitude and precipitation $\left(r_{s}=0.580\right.$; $p<0.001$ and $-0.562 ; p<0.001$, respectively), showing a clear response to variable moisture content (Table 2; Fig. 5). A high CPI is the main characteristic of leaf waxes, which must be related to leaf wax production that is not visible in the fatty acid abundance. The highest correlation of $n$-alkane CPI values was observed with distance to the coast $\left(r_{s}>0.4 ; p<0.001\right.$, Table 2$)$. The ACL of the fatty acids did not show high significant correlation (Table 2) but ACL of the $n$-alkanes correlates negatively with both, precipitation $\left(r_{s}=-0.416 ; p<0.001\right)$ and surface evaporation $\left(r_{s}=-0.485 ; p<0.001\right)$ (Fig. 5). The latter correlation, where lower moisture is related to higher abundance of longer carbon chain length of $n$-alkanes, confirm a direct response of the leaf wax distribution (ACL and CPI) to moisture gradients. Aridity has been proposed as a driver of $n$-alkane chain length, where drier conditions promote generally longer chain lengths (Dodd et al. 1998; Feakins and Sessions 2010; Hoffmann et al. 2013; Andrae et al. 2019). It is thought that under arid and usually warm conditions, selective pressures may favor the production of longer, more hydrophobic $n$-alkane chain lengths (Shepherd and Griffiths 2006; Bush and McInerney 2013). However, opposite trends between ACL and aridity have also been found in leaves and soils (Hoffmann et al. 2013; Carr et al. 2014; Jaeschke et al. 2018). The observed dissimilarities may thus relate to genetic or taxonomic differences besides being solely modulated by environmental parameters (Bush and McInerney 2013; Carr et al. 2014; Andrae et al. 2019; Xu et al. 2020).

\section{Leaf waxes to understand moisture at the dry limits of the hyperarid Atacama Desert}

Saturated long-chain $\left(>\mathrm{C}_{20}\right)$ fatty acids are the precursors for the biosynthesis of aliphatic cuticular wax components, such as primary and secondary alcohols, aldehydes, alkanes, ketones and alkyl esters (Kolattukudy 1966). In fact, Kolattukudy $(1966,1967)$ proposed an elongation-decarboxylation pathway for alkane biosynthesis. During this pathway, the shorter chain fatty acids $\left(<\mathrm{C}_{20}\right)$ are elongated by the stepwise addition of $\mathrm{C}_{2}$ units followed by decarboxylation until an appropriate length $\left(\mathrm{C}_{30}-\mathrm{C}_{32}\right)$ is reached. The resulting leaf wax $n$-alkanes then show the typical odd over even dominance (Kunst et al. 2006). The leaf wax trends observed in this study (Table 2) are related to leaf wax production under extremely low moisture conditions where CPI of fatty acids and ACL of $n$-alkanes correlate with moisture availability (Fig. 5). More studies are required to understand the 

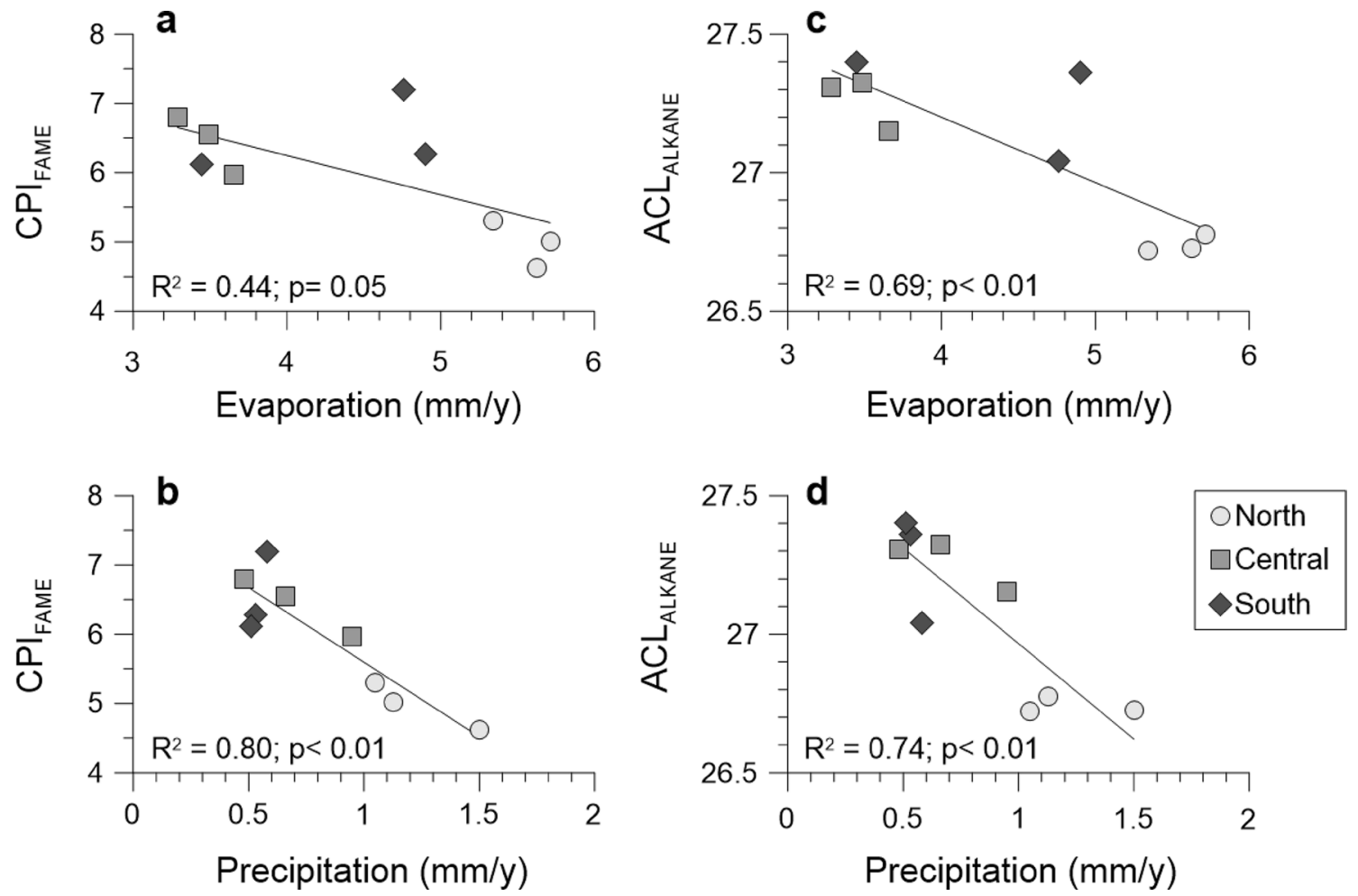

Fig. 5 Correlation between environmental parameters and chain length distributions of fatty acids CPI (a, b) and $n$-alkanes ACL (c, d) in Tillandsia landbeckii

full mechanisms behind this strong relationship with moisture for plants thriving at the dry limit.

\section{Conclusions}

This study investigated leaf wax $n$-alkane and fatty acid distributions in modern Tillandsia landbeckii plants located in isolated patches along the Coastal Cordillera of the Atacama Desert to investigate their potential as chemotaxonomic markers and dependency on climate. Our results show that Tillandsia plants produce more $n$-alkanes than fatty acids in their leaves likely as an expression of enhanced drought tolerance. While $n$-alkane and fatty acid concentrations and chain-length patterns are highly variable within a specific ecosystem, likely reflecting small-scale changes in moisture availability and natural variability, site-averaged values show significant correlations with annual precipitation and evaporation along the investigated coastal transect. Our results indicate sensitive changes in leaf wax composition of Tillandsia to subtle differences in climate parameters pointing to an adaptive strategy to the extremely arid conditions at the molecular level. The Tillandsia-specific chemical fingerprints can thus provide crucial information on past climate variability in the Atacama Desert.

\section{Information on Electronic Supplementary Material}

Online Resource 1. Comparison of leaf wax fatty acids and $n$-alkanes of Tillandsia landbeckii with those of two trees from a temperate forest in Chile.

Supplementary Information The online version contains supplementary material available at https://doi.org/10.1007/s00606-021-01800-0.

Acknowledgements This study was part of the CRC 1211 'Earth - Evolution at the dry limit' supported by the Deutsche Forschungsgemeinschaft (DFG, German Research Foundation) under Grant 268236062 - SFB 1211. SC and ML acknowledge the grant ANID FONDECYT 1190398. We thank F. McInerney and M. Koch for their valuable comments improving the quality of this manuscript.

Author contributions $\mathrm{SC}$ and $\mathrm{AJ}$ conceived and designed the project. AJ conducted the field work. ML, KG, SC and AJ analyzed the samples. MR provided WRF model data. SC and AJ drafted the manuscript. CL, MR, KG and JR reviewed the manuscript. All authors contributed to the final manuscript draft.

Funding Open Access funding enabled and organized by Projekt DEAL.

\section{Declarations}

Conflict of interest The authors declare that they do have no conflict of interest. 
Open Access This article is licensed under a Creative Commons Attribution 4.0 International License, which permits use, sharing, adaptation, distribution and reproduction in any medium or format, as long as you give appropriate credit to the original author(s) and the source, provide a link to the Creative Commons licence, and indicate if changes were made. The images or other third party material in this article are included in the article's Creative Commons licence, unless indicated otherwise in a credit line to the material. If material is not included in the article's Creative Commons licence and your intended use is not permitted by statutory regulation or exceeds the permitted use, you will need to obtain permission directly from the copyright holder. To view a copy of this licence, visit http://creativecommons.org/licenses/by/4.0/.

\section{References}

Andrae JW, McInerney FA, Tibby J, Henderson ACG, Hall PA, Marshall JC, McGregor GB, Barr C, Greenway M (2019) Variation in leaf wax n-alkane characteristics with climate in the broad-leaved paperbark (Melaleuca quinquenervia). Org Geochem 130:33-42. https://doi.org/10.1016/j.orggeochem.2019.02.004

Arroyo MTK, Squeo FA, Armesto JJ, Villagran C (1988) Effects of aridity on plant diversity in the northern Chilean Andes: results of a natural experiment. Ann Missouri Bot Gard 75:55-78

Benzing DH, Seeman J, Renfrow A (1978) The foliar epidermis in Tillandsioideae (Bromeliaceae) and its role in habitat selection. Amer J Bot 65:359-365. https://doi.org/10.2307/2442278

Bianchi TS, Canuel EA (2011) Lipids: fatty acids. In: Parrish CC (ed) Chemical biomarkers in aquatic ecosystems. Princeton University Press, Princeton, pp 144-168

Böhm C, Schween JH, Reyers M, Maier B, Löhnert U, Crewell S (2021) Toward a climatology of fog frequency in the Atacama Desert via multispectral satellite data and machine learning technique. J Appl Meteorol Climatol 60:1149-1169. https://doi.org/ 10.1175/JAMC-D-20-0208.1

Boom A, Carr AS, Chase BM, Grimes HL, Meadows ME (2014) Leaf wax n-alkanes and $813 \mathrm{C}$ values of CAM plants from arid southwest Africa. Org Geochem 67:99-102. https://doi.org/10.1016/j. orggeochem.2013.12.005

Borthagaray AI, Miguel A, Fuentes MA, Marquet PA (2010) Vegetation pattern formation in a fog-dependent ecosystem. $\mathrm{J}$ Theor Biol 265:18-26. https://doi.org/10.1016/j.jtbi.2010.04.020

Bush RT, McInerney F (2013) Leaf wax n-alkane distributions in and across modern plants: implications for paleoecology and chemotaxonomy. Geochim Cosmochim Acta 117:161-179. https://doi. org/10.1016/j.gca.2013.04.016

Bush RT, McInerney FA (2015) Influence of temperature and C4 abundance on n-alkane chain length distributions across the central USA. Org Geochem 79:65-73. https://doi.org/10.1016/j.orgge ochem.2014.12.003

Carr AS, Boom A, Grimes HL, Chase BM, Meadows ME, Harris A (2014) Leaf wax n-alkane distributions in arid zone South African flora: environmental controls, chemotaxonomy and palaeoecological implications. Org Geochem 67:72-84. https://doi.org/ 10.1016/j.orggeochem.2013.12.004

Caviedes C (1973) A climatic profile of the North Chilean desert at latitude $20^{\circ} \mathrm{S}$. In: Amiran DHK, Wilson AW (eds) Coastal deserts, their natural and human environments. University of Arizona Press, Tuscon, pp 115-121

Cerda-Peña C, Contreras S, Rau JR (2020) Molecular n-alkyl leaf waxes of three dominant plants from the temperate forest in South America. Org Geochem 149:104105. https://doi.org/10.1016/j. orggeochem.2020.104105
Cereceda P, Larraín H, Osses P, Farías M, Egaña I (2008) The spatial and temporal variability of fog and its relation to fog oases in the Atacama Desert, Chile. Atmos Res 87:312-323. https://doi.org/ 10.1016/j.atmosres.2007.11.012

Cifuentes G, Contreras S, Cerda-Peña C (2020) Evaluation of the foliar damage that threatens a millennial-age tree, Araucaria araucana (Molina) K. Koch, using leaf waxes. Forests 11:59. https://doi. org/10.3390/f11010059

Contreras S, Lange CB, Pantoja S, Lavik G, Rincón-Martínez D, Kuypers MMM (2010) A rainy northern Atacama Desert during the last interglacial. Geophys Res Lett 37:L23612. https://doi.org/ 10.1029/2010GL045728

Dee DP, Uppala SM, Simmons AJ, Berrisford P, Poli P, Kobayashi S, Andrae U, Balmaseda MA, Balsamo G, Bauer P, Bechtold P, Beljaars ACM, van de Berg L, Bidlot J, Bormann N, Delsol C, Dragani R, Fuentes M, Geer AJ, Haimberger L, Healy SB, Hersbach H, Hólm EV, Isaksen L, Kållberg P, Köhler M, Matricardi M, McNally AP, Monge-Sanz BM, Morcrette J-J, Park B-K, Peubey C, Rosnay P, Tavolato C, Thépaut J-N, Vitart F (2011) The ERA-Interim reanalysis: configuration and performance of the data assimilation system. Quart J Roy Meteorol Soc 137:553-597. https://doi.org/10.1002/qj.828

Del Río C, García JL, Osses P, Zanetta N, Lambert F, Rivera D, Siegmund A, Wolf N, Cereceda P, Larraín H, Lobos F (2018) ENSO influence on coastal fog-water yield in the Atacama Desert, Chile. Aerosol Air Qual Res 18:127-144. https://doi.org/10.4209/aaqr. 2017.01.0022

Del Río C, Lobos-Roco F, Latorre C, Koch MA, García JL, Osses P, Lambert F, Alfaro F, Siegmund A (2021) Spatial distribution and interannual variability of coastal fog and low clouds cover in the hyperarid Atacama Desert and implications for past and present Tillandsia landbeckii ecosystems. P1 Syst Evol 58:1-23. https:// doi.org/10.1007/s00606-021-01782-z

Diefendorf AF, Freimuth EJ (2017) Extracting the most from terrestrial plant-derived n-alkyl lipids and their carbon isotopes from the sedimentary record: a review. Org Geochem 103:1-21. https:// doi.org/10.1016/j.orggeochem.2016.10.016

Dodd RS, Rafii ZA, Power AB (1998) Ecotypic adaptation in Austrocedrus chilensis in cuticular hydrocarbon composition. New Phytol 138:699-708

Dragota S, Riederer M (2009) Comparative study on epicuticular leaf waxes of Araucaria araucana, Agathis robusta and Wollemia nobilis (Araucariaceae). Austral J Bot 56:644-650

Eglinton TI, Eglinton G (2008) Molecular proxies for paleoclimatology. Earth Planet Sci Lett 275:1-16. https://doi.org/10.1016/j.epsl. 2008.07.012

Eglinton G, Hamilton RJ (1967) Leaf epicuticular waxes. Science 156:1322

Feakins SJ, Sessions AL (2010) Crassulacean acid metabolism influences $\mathrm{D} / \mathrm{H}$ ratio of leaf wax in succulent plants. Org Geochem 41:1269-1276. https://doi.org/10.1016/j.orggeochem.2010.09.007

Feakins SJ, Peters T, Wu MS, Shenkin A, Salinas N, Girardin CA, Bentley LP, Blonder B, Enquist BJ, Martin RE, Asner GP, Malhi Y (2016) Production of leaf wax n-alkanes across a tropical forest elevation transect. Org Geochem 100:89-100. https://doi.org/10. 1016/j.orggeochem.2016.07.004

Finstad KM, Pfeiffer M, McNicol G, Tuite M, Williford K, Amundson R (2018) A late quaternary paleoenvironmental record in sand dunes of the northern Atacama Desert, Chile. Quatern Res 90:127-138. https://doi.org/10.1017/qua.2018.20

García J-L, Lobos-Roco F, Schween JH, del Río C, Osses P, Vives R, Pezoa M, Siegmund A, Latorre C, Alfaro F, Koch MA, Loehnert U (2021) Climate and coastal low-cloud dynamic in the hyperarid Atacama fog Desert and the geographic distribution of Tillandsia landbeckii (Bromeliaceae) dune ecosystems. Pl Syst Evol 307:57. https://doi.org/10.1007/s00606-021-01775-y 
Garreaud R, Barichivich J, Christie DA, Maldonado A (2008) Interannual variability of the coastal fog at Fray Jorge relict forests in semi- arid Chile. J Geophys Res 113:G04011. https://doi.org/10. 1029/2008JG000709

González AL, Fariña JM, Pinto R, Pérez C, Weathers KC, Armesto JJ, Marquet PA (2011) Bromeliad growth and stoichiometry: responses to atmospheric nutrient supply in fog-dependent ecosystems of the hyper-arid Atacama Desert, Chile. Oecologia 167:835-845. https://doi.org/10.1007/s00442-011-2032-y

Hartley AJ, Chong G, Houston J, Mather AE (2005) 150 million years of climatic stability: evidence from the Atacama Desert, northern Chile. J Geol Soc 162:421-424. https://doi.org/10. 1144/0016-764904-071

Haslam R, Borland A, Maxwell K, Griffiths H (2003) Physiological responses of the CAM epiphyte Tillandsia usneoides L. (Bromeliaceae) to variations in light and water supply. J Pl Physiol 160:627-634. https://doi.org/10.1078/0176-1617-00970

Hermida-Carrera C, Fares MA, Font-Carrascosa M, Kapralov MV, Koch MA, Mir A, Molins A, Ribas-Carbó M, Rocha J, Galmés J (2020) Exploring molecular evolution of Rubisco in C 3 and CAM Orchidaceae and Bromeliaceae. BMC Evol Biol 20:11. https://doi.org/10.1186/s12862-019-1551-8

Hoffmann B, Kahmen A, Cernusak LA, Arndt SK, Sachse D (2013) Abundance and distribution of leaf wax n-alkanes in leaves of Acacia and Eucalyptus trees along a strong humidity gradient in northern Australia. Org Geochem 62:62-67. https://doi.org/ 10.1016/j.orggeochem.2013.07.003

Houston J (2006) Variability of precipitation in the Atacama Desert: its causes and hydrological impact. Int J Climatol 26:21812198. https://doi.org/10.1002/joc.1359

Houston J, Hartley AJ (2003) The central Andean west-slope rainshadow and its potential contribution to the origin of hyperaridity in the Atacama Desert. Int J Climatol 23:1453-1464. https://doi.org/10.1002/joc. 938

Jaeschke A, Rethemeyer J, Lappé M, Schouten S, Boeckx P, Schefuß E (2018) Influence of land use on distribution of soil n-alkane $\delta \mathrm{D}$ and brGDGTs along an altitudinal transect in Ethiopia: Implications for (paleo)environmental studies. Org Geochem 124:77-87. https://doi.org/10.1016/j.orggeochem.2018.06.006

Jaeschke A, Böhm C, Merklinger FF, Bernasconi SM, Reyers M, Kusch S, Rethemeyer J (2019) Variation in $\delta 15 \mathrm{~N}$ of fog-dependent Tillandsia ecosystems reflect water availability across climate gradients in the hyperarid Atacama Desert. Global Planet Change 183:103029. https://doi.org/10.1016/j.glop.lacha.2019. 103029

Jansen B, Nierop K, Hageman J, Cleef AM, Verstraten JM (2006) The straight-chain lipid biomarker composition of plant species responsible for the dominant biomass production along two altitudinal transects in the Ecuadorian Andes. Org Geochem $37: 1514-1536$

Jeffree C (2006) The fine structure of the plant cuticle. Biol Pl Cuticle 23:11-125

Jetter R, Kunst L, Samuels AL (2006) Composition of plant cuticular waxes annual plant reviews volume 23: biology of the plant cuticle. Blackwell Publishing Ltd, Oxford, pp 145-181

Knief C, Bol R, Amelung W, Kusch S, Frindte K, Eckmeier E, Jaeschke A, Dunai T, Fuentes B, Mörchen R, Schütte T, Lücke A, Klumpp E, Kaiser K, Rethemeyer J (2020) Tracing elevational changes in microbial life and organic carbon sources in soils of the Atacama Desert. Global Planet Change 184:103078. https://doi.org/10. 1016/j.gloplacha.2019.103078

Koch K, Ensikat HJ (2008) The hydrophobic coatings of plant surfaces: epicuticular wax crystals and their morphologies, crystallinity and molecular self-assembly. Micron 39:759-772
Koch MA, Kleinpeter D, Auer E, Siegmund A, del Río C, Osses P, García JL, Marzol MV, Zizka G, Kiefer C (2019) Living at the dry limits. Ecological genetics of Tillandsia lomas in the Chilean Atacama Desert. Pl Syst Evol 305:1041-1053. https://doi.org/10. 1007/s00606-019-01623-0

Koch MA, Stock C, Kleinpeter D, del Río C, Osses P, Merklinger FF, Quandt D, Siegmund A (2020) Vegetation growth and landscape genetics of Tillandsia lomas at their dry limits in the Atacama Desert show fine-scale response to environmental parameters. Ecol Evol 10:13260-13274. https://doi.org/10.1002/ece3.6924

Kolattukudy PE (1966) Biosynthesis of wax in Brassica oleracea. Relation of fatty acid to wax. Biochemistry 5:2265-2275

Kolattukudy PE (1967) Biosynthesis of paraffins in Brassica oleracea: fatty acid elongation-decarboxylation as a plausible pathway. Phytochemistry 6:963-975. https://doi.org/10.1016/S0031-9422(00) 86048-3

Kolattukudy PE, Espelie K (1985) Chapter 8-Biosynthesis of Cutin, Suberin, and Associated Waxes. In: Higuchi T (ed) Biosynthesis and Biodegradation of Wood Components. Academic Press, pp 161-207. https://doi.org/10.1016/B978-0-12-347880-1.50012-X

Kosma DK, Bourdenx B, Bernard A, Parsons EP, Lu S, Joubes J, Jenks MA (2009) The impact of water deficiency on leaf cuticle lipids of Arabidopsis. Pl Physiol 151:1918-1929

Kunst L, Samuels A (2003) Biosynthesis and secretion of plant cuticular wax. Prog Lipid Res 42:51-80

Kunst L, Jetter R, Samuels AL (2006) Biosynthesis and transport of plant cuticular waxes. In: Riederer M, Müller C (Eds) Biology of the plant cuticle, vol. 23. Blackwell Publishing Ltd, pp 182-215. https://doi.org/10.1002/9781119312994.apr0233

Latorre C, Gonzáles AL, Quade J, Farina JM, Pinto R, Marquet PA (2011) Establishment and formation of fog-dependent Tillandsia landbeckii dunes in the Atacama Desert: Evidence from radiocarbon and stable isotopes. J Geophys Res 116:G03033. https://doi. org/10.1029/2010JG001521

Lobos-Roco F, Vilà-Guerau de Arellano J, Pedruzo-Bagazgoitia X (2018) Characterizing the influence of the marine stratocumulus cloud on the land fog at the Atacama Desert. Atmos Res 214:109120. https://doi.org/10.1016/j.atmosres.2018.07.009

McKay CP, Friedmann EI, Gomez-Silva B, Carceres-Villanueva L, Andersen DT, Landheim R (2003) Temperature and moisture conditions for life in the extreme arid region of the Atacama Desert: Four years of observation including the El Niño of 1997-1998. Astrobiology 3:393-406. https://doi.org/10.1089/1531107037 69016460

Merklinger FF, Zheng Y, Luebert F, Harpke D, Böhnert T, Stoll A, Koch MA, Blattner FR, Wiehe T, Quandt D (2020) Population genomics of Tillandsia landbeckii reveals unbalanced genetic diversity and founder effects in the Atacama Desert. Global Planet Change 184:103076. https://doi.org/10.1016/j.gloplacha. 2019.103076

Mörchen R, Amelung W, Giese C, Böhnert T, Ruhm J, Lehndorff E (2021) Fingerprint of plant life in the Atacama Desert-Insights from n-alkane analyses. Org Geochem 151:104145. https://doi. org/10.1016/j.orggeochem.2020.104145

Müller C, Riederer M (2005) Plant surface properties in chemical ecology. J Chem Ecol 3:2621-2651

Muñoz R, Quintana J, Falvey M, Rutllant J, Garreaud R (2016) Coastal clouds at the eastern Margin of the southeast Pacific: climatology and trends. J Clim 29:4525-4542. https://doi.org/10.1175/ JCLI-D-15-0757.1

Oka S, Ogawa H (1984) The distribution of Lomas vegetation and its climatic environments along the Pacific Coast of Peru. Geogr Rep Tokyo Metrop Univ 19:113-125

Ono M (1986) Taxomonic and ecological studies on the lomas vegetation in the Pacific coast of Peru. Reports of Overseas Scientific 
Survey. Makino Herbarium, Tokyo Metropolitan University, Tokyo

Osmond C, Adams W, Smith S (1989) Crassulacean acid metabolism. In: Pearcy R, Ehleringer JR, Mooney H, Rundel P (eds) Plant physiological ecology. Chapman and Hall, New York, pp 258-280

Pinto R, Barria I, Marquet PA (2006) Geographical distribution of Tillandsia lomas in the Atacama Desert, northern Chile. J Arid Environm 65:543-552. https://doi.org/10.1016/j.jaridenv.2005. 08.015

Prohaska FJ (1973) New evidence on the climatic controls along the Peruvian coast. In: Amiran DHK, Wilson AW (eds) Coastal deserts, their natural and human environments. University of Arizona Press, Tuscon, p 91-107

Rafii ZA, Dodd RS (1998) Genetic diversity among Coastal and Andean natural populations of Araucaria araucana (Molina) K. Koch. Biochem Syst Ecol 26:441-451. https://doi.org/10.1016/ S0305-1978(97)00125-7

Raux PS, Gravelle S, Dumais J (2020) Design of a unidirectional water valve in Tillandsia. Nature Commun 11:1-7. https://doi.org/10. 1038/s41467-019-14236-5

Reyers M (2019) WRF output daily accumulated precipitation 10 $\mathrm{km}$ Atacama. CRC1211 Database (CRC1211DB). Available at: https://doi.org/10.5880/CRC1211DB.20

Reyers M, Böhm C, Shau Y, Crewell S (2021) Synoptic-to-regionalscale analysis of rainfall in the Atacama Desert $\left(18^{\circ}-26^{\circ} \mathrm{S}\right)$ using a long-term simulation with WRF. Monthly Weath Rev 149:91112. https://doi.org/10.1175/MWR-D-20-0038.s1

Riederer M, Schreiber L (2001) Protecting against water loss: analysis of the barrier properties of plant cuticles. J Exp Bot 52:2023-2032

Ritter B, Wennrich V, Medialdea A, Brill D, King G, Schneiderwind S, Niemann K, Fernández-Galego E, Diederich J, Rolf C, Bao R, Melles M, Dunai T (2019) Climatic fluctuations in the hyperarid core of the Atacama Desert during the past $215 \mathrm{ka}$. Sci Rep 9:5270. https://doi.org/10.1038/s41598-019-41743-8

Ruiz-Ruiz PA, Contreras S, Urzua A, Quiroga E, Rebolledo L (2021) Fatty acid biomarkers in three species inhabiting a high latitude Patagonian fjord (Yendegaia Fjord, Chile). Polar Biol 44:147-162. https://doi.org/10.1007/s00300-020-02788-y

Rundel PW, Dillon MO (1998) Ecological patterns in the Bromeliaceae of the lomas formations of Coastal Chile and Peru. Pl Syst Evol 212:261-278

Rundel PW, Dillon MO, Palma B, Mooney HA, Gulmon SL, Ehleringer JR (1991) The phytogeography and ecology of the Coastal Atacama and Peruvian Deserts. Aliso 13:1-49

Rundel PW, Palma B, Dillon MO, Sharifi MR, Nilsen ET, Boonpragob K (1997) Tillandsia landbeckii in the coastal Atacama Desert of northern Chile. Rev Chil Hist Nat 70:341-349

Sachse D, Radke J, Gleixner G (2006) $\Delta$ D values of individual n-alkanes from terrestrial plants along a climatic gradient implications for the sedimentary biomarker record. Org Geochem 37:469-483. https://doi.org/10.1016/j.orggeochem.2005.12.003

Schulz N, Boisier JP, Aceituno P (2011) Climate change along the arid coast of northern Chile. J Clim 32:1803-1814. https://doi.org/10. $1002 /$ joc. 2395

Schuster AC, Burghardt M, Alfarhan A, Bueno A, Hedrich R, Leide J, Thomas J, Riederer M (2016) Effectiveness of cuticular transpiration barriers in a desert plant at controlling water loss at high temperatures. AoB PLANTS 8:plw027
Schween JH, Hoffmeister D, Loehnert U (2020) Filling the observational gap in the 921 Atacama Desert with a new network of climate stations. Global Planet Change 184:103034. https://doi.org/ 10.1016/j.gloplacha.2019.103034

Sharma P, Kothari SL, Rathore MS, Gour VS (2018) Properties, variations, roles, and potential applications of epicuticular wax: a review. Turk J Bot 42:135-149. https://doi.org/10.3906/ bot-1702-25

Shepherd T, Griffiths DW (2006) The effects of stress on plant cuticular waxes. New Phytol 171:469-499

Skamarock WC, Klemp JB, Dudhia J, Gill DO, Barker D, Duda MG, Huang X, Wang W, Powers JG (2008) A description of the Advanced Research WRF version 3. NCAR Tech. Note NCAR/ TN-4751STR, pp 113. https://doi.org/10.5065/D68S4MVH

Smith LB, Downs RJ (1977) Tillandsioideae (Bromeliaceae). Fl Neotrop Monogr 14:888

Struck J, Bliedtner M, Strobel P, Schumacher J, Bazarradnaa E, Zech R (2020) Leaf wax n-alkane patterns and compound-specific d13C of plants and topsoils from semi-arid and arid Mongolia. Biogeosciences 17:567-580. https://doi.org/10.5194/bg-17-567-2020

Tafolla-Arellano JC, González-León A, Tiznado-Hernández ME, Zacarías García L, Báez-Sañudo R (2013) Composición, fisiología y biosíntesis de la cutícula en plantas. Rev Fitotec Mex 36:3-12

Takahashi K, Battisti DS (2007) Processes controlling the mean tropical pacific precipitation pattern. Part II: the SPCZ and the Southeast Pacific dry zone. J Clim 20:5696-5706

Till W (1992) Die Untergattung Diaphoranthema von Tillandsia, 4. Teil: Das Tillandsia recurvata Aggregat. Die Bromelie 1:15-20

Voigt C, Klipsch S, Herwartz D, Chong G, Staubwasser M (2020) The spatial distribution of soluble salts in the surface soil of the Atacama Desert and their relationship to hyperaridity. Global Planet Change 184:103077. https://doi.org/10.1016/j.gloplacha. 2019.103077

Westbeld A, Klemm O, Grießbaum F, Sträter E, Larrain H, Osses P, Cereceda P (2009) Fog deposition to a Tillandsia carpet in the Atacama Desert. Ann Geophys 27:3571-3576. https://doi.org/10. 5194/angeo-27-3571-2009

Xu X, Xiao L, Feng J, Chen N, Chen Y, Song B, Xue K, Shi S, Zhou Y, Jenks MA (2016) Cuticle lipids on heteromorphic leaves of Populus euphratica Oliv. growing in riparian habitats differing in available soil moisture. Physiol Pl 158:318-330

Xu X, Chen N, Feng J, Zhou M, He J, Zou Y, Shi S, Zhou J, Jenks MA (2020) Comparative analyses of leaf cuticular lipids of two succulent xerophytes of the Ordos Plateau (Gobi Desert), Tetraena mongolica maxim and Zygophyllum xanthoxylum (Bunge) Engl. Environm Exp Bot 177:104129. https://doi.org/10.1016/j.envex pbot.2020.104129

Publisher's Note Springer Nature remains neutral with regard to jurisdictional claims in published maps and institutional affiliations. 